\title{
Hubungan Kecemasan, Depresi Dan Stres Dengan Kualitas Tidur Mahasiswa Fakultas Kedokteran Selama Pandemi Covid-19
}

\author{
*Nida Faradisa Fauziyah ${ }^{1}$, Khatifah Nur Aretha ${ }^{1}$ \\ ${ }^{1}$ Fakultas Kedokteran Universitas Muhammadiyah Surakarta
}

\author{
*) Correspondence Author \\ Nida Faradisa Fauziyah \\ Fakultas Kedokteran Universitas Muhammadiyah Surakarta \\ Email:nff220@ums.ac.id
}

\begin{abstract}
Coronavirus disease 2019 (COVID-19) is a sustainable health problem in 200 countries around the world. Public health emergency condition during pandemics such as SARS, MERS and Ebola are associated with increased psychological distress in the affected population. Negative impacts such as anxiety, depression and stress on students may become a burden on the mental and emotional health of students which in turn will affect the quality of student sleep. The author was interested in knowing about the relationship between anxiety, depression and stress with the quality of sleep of medical students during the COVID-19 pandemic. This study used an analytic observational study design with a cross sectional approach. This study was conducted in December with 81 students as respondents. This study used the DASS-42 questionnaire to measure anxiety, depression, stress and the PSQI to measure sleep quality. The results showed that $32.1 \%, 27.2 \%, 42 \%$ and $48.1 \%$ of students experienced anxiety, depression, stress and poor sleep quality. Statistical data measurement was done by using logistic regression, the results obtained $p$ value $=0.030$ (OR 3.967, 95\% CI [1.143-13.722]), $\mathrm{p}=0.004$ (OR 11.456, 95\% CI $[2,217-59,196]), \mathrm{p}=0.043$ (OR $0.314,95 \%$ CI [0.102-0.962]). From this study it can be concluded that anxiety, depression and stress had correlation with the sleep quality of students at the Faculty of Medicine, Muhammadiyah University of Surakarta during the COVID-19 pandemic.
\end{abstract}

Keywords: anxiety, depression, stress, sleep quality, college students

\begin{abstract}
Abstrak
Penyakit Coronavirus 2019 (COVID-19) menjadi masalah kesehatan berkelanjutan pada 200 negara di dunia. Keadaan darurat kesehatan masyarakat selama pandemi seperti SARS, MERS dan Ebola dikaitkan dengan peningkatan tekanan psikologis pada populasi yang terkena. Dampak negatif seperti kecemasan, depresi dan stres pada mahasiswa dapat menjadi beban pada kesehatan mental dan emosional para mahasiswa yang nanti pada akhirnya akan mempengaruhi kualitas tidur mahasiswa. Penulis tertarik untuk mengetahui tentang hubungan kecemasan, depresi dan stres dengan kualitas tidur mahasiswa fakultas kedokteran selama masa pandemi COVID-19. Penelitian menggunakan desain penelitian observasional analitik dengan pendekatan cross sectional. Penelitian ini dilakukan pada bulan Desember dengan jumlah responden penelitian 81 mahasiswa. Penelitian ini menggunakan kuesioner DASS- 42 untuk mengukur kecemasan, depesi, stres dan PSQI untuk mengukur kualitas tidur. Hasil penelitian menunjukkan 32,1\%, 27,2\%, 42\% dan 48,1\% mahasiswa mengalami kecemasan, depresi, stres dan kualitas tidur yang buruk. Data statistic menggunakan regresi logistic didapatkan hasil nilai $\mathrm{p}=0,030$ (OR 3,967, 95\% CI [1,143-13,722]), p=0,004 (OR 11,456, 95\% CI [2,217-59,196]), p=0,043(OR 0,314, 95\% CI [0,102-0,962]). Kesimpulan penelitian adalah terdapat hubungan kecemasan, depresi dan stres dengan kualitas tidur mahasiswa Fakultas Kedokteran Universitas Muhammadiyah Surakarta selama masa pandemik COVID-19.
\end{abstract}

Kata kunci : kecemasan, depresi, stres, kualitas tidur, mahasiswa 


\section{PENDAHULUAN}

Pada akhir tahun 2019, pneumonia dengan penyebab yang tidak diketahui pertama kali terdeteksi di Wuhan, wilayah metropolitan terbesar di Cina Provinsi Hubei. Sebulan kemudian pada tanggal 30 Januari 2020 WHO mengumumkan ke publik tentang wabah penyakit Coronavirus 2019 (COVID-19) yang menjadi masalah kesehatan berkelanjutan di lebih dari 200 negara di dunia sebagai Public Health Emergency Of International Concern $(\mathrm{PHEIC})^{1}$. Indonesia mengkonfirmasi pasien COVID pertama pada tanggal 2 Maret 2020 dan pada tanggal 10 Maret 2021 sudah tercatat sebanyak 1,3 juta kasus di Indonesia ${ }^{2}$.

Keadaan darurat kesehatan masyarakat selama pandemi seperti SARS, MERS dan Ebola dikaitkan dengan peningkatan tekanan psikologis pada populasi yang terkena ${ }^{3.4}$. Perilaku maladaptif, emosional dan reaksi defensif adalah beberapa tanggapan psikologis terhadap pandemi ${ }^{5}$. Isolasi sosial ditemukan sangat terkait dengan kecemasan, depresi, menyakiti diri sendiri, dan kecenderungan bunuh diri ${ }^{6}$ Isolasi, kebosanan, frustrasi, kekhawatiran tertular infeksi, kurangnya kebebasan, kekhawatiran terhadap keluarga atau teman adalah beberapa faktor yang mungkin terjadi mempengaruhi kesehatan mental selama karantina $^{7}$. Kualitas tidur buruk dan peningkatan tekanan psikologis juga didokumentasikan dengan baik selama pandemi sebelumnya.
Penelitian sebelumnya di Cina tentang dampak psikologis masyarakat terhadap pandemik Covid-19 ditemukan sebanyak $53,8 \%$ responden memiliki dampak psikologis dari sedang hingga berat, sebanyak $16,5 \%$ responden memiliki gejala depresi sedang hingga berat, $28,8 \%$ responden memiliki gejala kecemasan sedang hingga berat dan $8,1 \%$ melaporkan tingkat stres sedang hingga berat $^{8}$. Hasil penelitian di Itali mengungkapkan bahwa $57,1 \%$ responden mengalami kualitas tidur yang buruk, 32,1\% memiliki tingkat gejala kecemasan umum yang tinggi dan $41,8 \%$ mengalami tekanan psikologis akibat pandemik Covid$19^{9}$.

Dampak negatif pandemi ini dapat dikaitkan dengan tantangan yang dihadapi oleh mahasiswa kedokteran dalam hal akademisi, ketidakpastian tentang masa depan, takut terinfeksi, berita tentang kekurangan alat pelindung diri, karantina menimbulkan kebosanan, frustrasi, kurangnya kebebasan, dan ketakutan yang disebabkan oleh rumor dan berita menyesatkan di media 10,11. Mahasiswa kedokteran menghadapi tantangan tersendiri seperti perubahan mendadak rutinitas pelatihan ketrampilan, termasuk pembelajaran dan ujian secara online, kontak dengan pasien dan interaksi dengan teman sebaya. Perubahan ini menyebabkan meningkatnya waktu menatap layar serta dapat menimbulkan hambatan pada pelatihan ketrampilan mereka. Semua faktor ini pada akhirnya dapat membebani kesehatan mental dan emosional para 
mahasiswa yang nanti pada akhirnya akan mempengaruhi kualitas tidur ${ }^{12}$.

Pada penelitian terbaru terhadap mahasiswa kedokteran di India selama wabah COVID-19, ditemukan bahwa terjadi peningkatan yang signifikan pada prevalensi, tingkat kecemasan dan stres, akan tetapi tidak ada perubahan pada depresi selama wabah dan karantina COVID-19. Peningkatan tersebut terlepas dari jenis kelamin, tahun studi, tempat tempat tinggal dan pendapatan bulanan keluarga. Mahasiswa kedokteran juga memiliki kualitas tidur yang buruk ${ }^{12}$.

Studi sebelumnya menunjukkan bahwa keadaan pandemi berdampak negatif pada kesehatan mental petugas kesehatan ${ }^{13}$. Sayangnya, penelitian tentang dampak pandemi pada kesehatan mental dan kualitas tidur para mahasiswa kedokteran masih sangat terbatas. Berdasarkan pemaparan di atas, penulis tertarik untuk mengetahui tentang hubungan kecemasan, depresi dan stres dengan kualitas tidur mahasiswa fakultas kedokteran selama masa pandemi COVID-19.

\section{METODE}

Penelitian ini menggunakan desain penelitian observasional analitik dengan pendekatan cross sectional dan dilakukan pada bulan Desember 2020 pada mahasiswa kedokteran. Jumlah responden penelitian ini adalah 120 mahasiswa tetapi hanya 81 mahasiswa yang bersedia menjadi responden dan mengisi kuesioner secara lengkap. Teknik pengambilan sampel adalah menggunakan yang teknik purposive sampling. Pengukuran status mental untuk mengetahui kecemasan, depresi dan stres pada mahasiswa dengan menggunakan kuesioner DASS 42 dengan skor cemas $>7$, tidak cemas $\leq 7$, depresi $>9$, tidak depresi $\leq 9$, stres $>14$, tidak stres $\leq 14$. Kuesioner PSQI digunakan untuk mengetahui kualitas tidur dengan kualitas tidur baik jika skor $\leq 5$ dan kualitas tidur buruk jika skor $>5$. Data bivariat dianalisis menggunakan uji chi-square dan data multivariat menggunakan uji regresi logistik. Penelitian ini juga telah mendapat persetujuan dan dinyatakan lolos etik oleh Komite Etik Penelitian Kesehatan (KEPK) FK UMS nomer 3389/B.2/KEPKFKUMS/III/2021.

\section{HASIL}

\section{Analisis deskripstif}

Penelitian ini telah dilakukan secara online dengan pengisian google form. Responden yang mengikuti penelitian ini adalah mahasiswa Fakultas Kedokteran Universitas Muhammadiyah Surakarta semester 3 sejumlah 81 mahasiswa yang bersedia mengisi kuesioner dan telah mengisi kuesioner secara lengkap. 
Tabel 1. Analisis univariat

\begin{tabular}{lll}
\hline Variabel & Jumlah & $\begin{array}{l}\text { Presentase } \\
(\%)\end{array}$ \\
\hline $\begin{array}{l}\text { Kecemasan } \\
\text { Tidak Cemas }\end{array}$ & 55 & 67,9 \\
$\quad$ Cemas & 26 & 32,1 \\
$\quad$ Depresi & & \\
$\quad$ Tidak Depresi & 59 & 72,8 \\
$\quad$ Depresi & 22 & 27,2 \\
Stres & & \\
$\quad$ Tidak stres & 47 & 58 \\
$\quad$ Stres & 34 & 42 \\
Kualitas tidur & & \\
Buruk & 39 & 48,1 \\
Baik & 42 & 51,9 \\
\hline
\end{tabular}

Sumber : data primer, 2020

Data dari tabel 1 menunjukkan jumlah responden dalam penelitian adalah sebanyak 81 mahasiswa. Sebanyak $26(32,1 \%)$ mahasiswa mengalami kecemasan, 22 (27,2\%) mahasiswa mengalami depresi, $34(42 \%)$ mahasiswa mengalami stres dan $39(48,1 \%)$ mahasiswa mengalami kualitas tidur yang buruk.

Analisis bivariat Hubungan antara kecemasan dengan kualitas tidur

Tabel 2. Hasil analisis bivariat kecemasan dengan kualitas tidur

\begin{tabular}{|c|c|c|c|c|c|c|}
\hline \multirow{2}{*}{$\begin{array}{l}\text { Karakte } \\
\text { ristik } \\
\text { Kecem } \\
\text { asan }\end{array}$} & \multicolumn{4}{|c|}{ Kualitas tidur } & \multirow[t]{2}{*}{$\mathrm{p}$} & \multirow{3}{*}{$\begin{array}{c}\text { OR } \\
(95 \% \mathrm{CI})\end{array}$} \\
\hline & \multicolumn{2}{|c|}{ Baik } & \multicolumn{2}{|c|}{ Buruk } & & \\
\hline & $\mathrm{F}$ & $\%$ & $\mathrm{~F}$ & $\%$ & & \\
\hline $\begin{array}{l}\text { Tidak } \\
\text { cemas }\end{array}$ & 36 & 65,45 & 19 & 34,55 & 0,000 & 6,316 \\
\hline Cemas & 6 & 23,08 & 20 & 76,92 & & $\begin{array}{l}(2,170- \\
18,381)\end{array}$ \\
\hline Jumlah & 42 & 51,85 & 39 & 48,15 & & \\
\hline
\end{tabular}

Sumber : data primer, 2020

Tabel 2 menunjukkan sebanyak 55 mahasiswa yang tidak cemas, ada $36(65,45 \%)$ mahasiswa memiliki kualitas tidur yang baik dan 19 (34,55\%) mahasiswa mengalami kualitas tidur yang buruk. Sementara itu, sebanyak 26 mahasiswa yang mengalami cemas, ada 6 $(23,08 \%)$ mahasiswa memiliki kualitas tidur yang baik dan $20(76,92 \%)$ mahasiswa memiliki kualitas tidur yang buruk. Pada uji statistik menunjukkan nilai $\mathrm{p}=$ 0,000, yang artinya adanya hubungan yang signifikan antara kecemasan dengan kualitas tidur. Nilai odd ratio sebesar 6,316 dengan nilai CI antara 2,170 hingga 18,381, yang artinya bahwa responden yang mengalami kecemasan memiliki risiko mendapatkan kualitas tidur buruk sebesar 6,316 kali lebih tinggi dibandingkan responden yang tidak mengalami kecemasan.

Hubungan antara depresi dengan kualitas tidur

Tabel 3. Hasil analisis bivariat depresi dengan kualitas tidur

\begin{tabular}{|c|c|c|c|c|c|c|}
\hline \multirow{2}{*}{$\begin{array}{l}\text { Karakteristik } \\
\text { Depresi }\end{array}$} & \multicolumn{4}{|c|}{ Kualitas tidur } & \multirow[t]{2}{*}{$\mathrm{p}$} & \multirow{2}{*}{$\begin{array}{c}\text { OR } \\
(95 \% \mathrm{CI})\end{array}$} \\
\hline & \multicolumn{2}{|c|}{ Baik } & \multicolumn{2}{|c|}{ Buruk } & & \\
\hline & $\mathrm{F}$ & $\%$ & $\mathrm{~F}$ & $\%$ & \multirow{5}{*}{0,000} & \\
\hline \multirow{4}{*}{$\begin{array}{l}\text { Tidak } \\
\text { depresi } \\
\text { Depresi }\end{array}$} & 40 & 67,8 & 19 & 32,2 & & 21,053 \\
\hline & & 0 & & 0 & & \\
\hline & 2 & 9,10 & 20 & 90,9 & & $(4,456-$ \\
\hline & & & & 0 & & $99,462)$ \\
\hline \multirow[t]{2}{*}{ Jumlah } & 42 & 51,8 & 39 & 48,1 & & \\
\hline & & 5 & & 5 & & \\
\hline
\end{tabular}

Sumber : Data primer, 2020

Pada tabel 3 menunjukkan sebanyak 59 mahasiswa yang tidak depresi, terdapat $40(67,80 \%)$ mahasiswa memiliki kualitas tidur yang baik dan 19 (32,20\%) mahasiswa mengalami kualitas tidur yang buruk. Sementara itu, sebanyak 22 mahasiswa yang mengalami depresi, terdapat $2(9,10 \%)$ mahasiswa 
memiliki kualitas tidur yang baik dan 20 (90,90\%) mahasiswa memiliki kualitas tidur yang buruk. Pada uji statistic diperoleh nilai $\mathrm{p}=0,000$ yang menunjukkan adanya hubungan yang signifikan antara depresi dengan kualitas tidur. Nilai odd ratio sebesar 21,053 dengan nilai CI antara 2,170 hingga 99,462, yang artinya bahwa responden yang mengalami depresi memiliki risiko mendapatkan kualitas tidur buruk sebesar 21,053 kali lebih tinggi dibandingkan responden yang tidak mengalami depresi.

Hubungan antara stres dengan kualitas tidur

Tabel 4. Hasil analisis bivariat stres dengan kualitas tidur

$\begin{array}{llll}\text { Karakteristik } & \text { Kualitas tidur } & \text { p } & \begin{array}{c}\text { OR } \\ (95 \%\end{array}\end{array}$

CI)

\begin{tabular}{lcccccc} 
Stres & \multicolumn{2}{c}{ Baik } & \multicolumn{2}{c}{ Buruk } & & \\
\hline & F & $\%$ & F & $\%$ & & \\
Tidak stres & 40 & 85,11 & 7 & 14,89 & 0,000 & 59,048 \\
Stres & 3 & 8,82 & 31 & 91,18 & & $(14,109-$ \\
& & & & & & $247,115)$
\end{tabular}

$\begin{array}{lllll}\text { Jumlah } & 43 & 53,09 & 38 & 46,91\end{array}$

Sumber: Data primer, 2020

Tabel 3 menunjukkan data sebesar 47 mahasiswa yang tidak stres terdapat $40(85,11 \%)$ mahasiswa memiliki kualitas tidur yang baik dan 7 (14,89\%) mahasiswa mengalami kualitas tidur yang buruk. Sementara itu, sebanyak 34 mahasiswa yang mengalami depresi, terdapat $3(8,82 \%)$ mahasiswa memiliki kualitas tidur yang baik dan $31(91,18 \%)$ mahasiswa memiliki kualitas tidur yang buruk. Pada uji statistik diperoleh nilai $\mathrm{p}=0,000$ yang menunjukkan adanya hubungan yang signifikan antara stres dengan kualitas tidur. Nilai odd ratio sebesar 59,048 dengan nilai CI antara 14,109 hingga 247,115 , yang artinya bahwa responden yang mengalami stres memiliki risiko mendapatkan kualitas tidur buruk sebesar 59,048 kali lebih tinggi dibandingkan responden yang tidak mengalami stres.

Analisis multivariat

Tabel 5. Hubungan kecemasan, depresi dan stres dengan kualitas tidur pada mahasiswa fakultas kedokteran selama masa pandemi Covid-19

\begin{tabular}{lccccc}
\hline Variabel & $\begin{array}{c}\text { Koefis } \\
\text { ien }\end{array}$ & $\mathrm{p}$ & $\begin{array}{c}\text { Exp } \\
(\mathrm{B})\end{array}$ & $\mathrm{CI}$ & $\mathrm{R}$ \\
\hline Kecemasan & 1,378 & 0,030 & 3,967 & $\begin{array}{c}1,143- \\
13,722\end{array}$ & 0,463 \\
Depresi & 2,438 & 0,004 & $\begin{array}{c}11,45 \\
6\end{array}$ & $\begin{array}{c}2,217- \\
59,196\end{array}$ & \\
Stres & $-1,158$ & 0,043 & 0,314 & $0,102-$ & 0,962 \\
Konstanta & $-0,522$ & 0,222 & 0,593 & & \\
\hline Sumber : Data primer, 2020 & & & &
\end{tabular}

Berdasarkan tabel 5 hasil uji regresi logistik pada variabel kecemasan menunjukkan nilai $\mathrm{p}=0,030$ $(\mathrm{p}<0,05)$ yang menyatakan ada hubungan antara kecemasan dan kualitas tidur. Pada variabel depresi menunjukkan nilai $\mathrm{p}=0,004 \quad(\mathrm{p}<0,05)$ yang menyatakan ada hubungan antara depresi dengan kualitas tidur. Nilai p pada variable stres menunjukan nilai $0,043(\mathrm{p}<0,05)$ yang menunjukkan ada hubungan antara stres dengan kualitas tidur. Secara keseluruhan didapatkan kesimpulan bahwa ada hubungan antara kecemasan, depresi dan stres dengan kualitas tidur mahasiswa fakultas kedokteran selama masa pandemik Covid-19. Variabel yang paling dominan berhubungan dengan kualitas tidur adalah depresi dengan nilai $\mathrm{p}=$ 0,004 dan nilai OR (exp.B) $=11,456 ; \mathrm{CI}=2,217$ 59,196 , yang artinya bahwa mahasiswa yang depresi 
akan berisiko 11,4 kali mengalami kualitas tidur yang buruk. Nilai $\mathrm{R}=0,463$ menunjukkan bahwa variable cemas, depresi dan stres mempengaruhi kualitas tidur sebesar $46,3 \%$ dan sebanyak $53,7 \%$ dipengaruhi oleh variable lainnya.

\section{PEMBAHASAN}

Penelitian ini menunjukkan sebanyak $32,1 \%$ mahasiswa mengalami kecemasan, 27,2\% mahasiswa mengalami depresi dan $42 \%$ mahasiswa mengalami stres. Penelitian di India menunjukkan 35,5\% (95\% CI $[29,1-42,2 \%]), 33,2 \% \quad(95 \%$ CI $\quad[27-39,9 \%])$ dan $24,9 \% \quad(95 \%$ CI $[19,3-31,2 \%])$ dari mahasiswa kedokteran sarjana, termasuk mahasiswa residen menunjukkan gejala depresi, kecemasan, dan stres selama pandemi COVID-19 dengan 23,9\%, 26,7\% dan $11,5 \%$ dari populasi studi memiliki tingkat depresi, kecemasan, dan stres sedang hingga sangat parah ${ }^{12}$. Studi di Cina menyebutkan bahwa insiden gangguan kesehatan mental pada masyarakat umum di Tiongkok selama 1 bulan relatif rendah ${ }^{14}$. Dampak negatif pandemi ini dapat dikaitkan denganm tantangan yang dihadapi oleh mahasiswa kedokteran dalam hal akademisi, ketidakpastian tentang masa depan, takut terinfeksi, berita tentang kekurangan alat pelindung diri, karantina menyebabkan kebosanan, frustrasi, kurangnya kebebasan, dan ketakutan yang disebabkan oleh rumor dan berita menyesatkan di media ${ }^{10,11}$.

Analisis bivariat pada penelitian ini menunjukkan adanya hubungan yang signifikan antara kecemasan dengan kualitas tidur dengan nilai $\mathrm{p}=0,000$, depresi dengan kualitas tidur dengan nilai $\mathrm{p}=0,000$ dan stres dengan kualitas tidur dengan nilai $\mathrm{p}=0,000$. Hasil penelitian ini sama dengan hasil penelitian yang dilakukan Al-Khani di Arab Saudi yang menunjukkan bahwa kualitas tidur secara signifikan dikaitkan dengan depresi, kecemasan, dan stres dengan nilai p masingmasing $(\mathrm{p}=0,013), \quad(\mathrm{p}=0,003) \quad$ dan $\quad(\mathrm{p}=0.004) \quad$ pada mahasiswa kedokteran ${ }^{15}$. Penelitian lain juga menyebutkan bahwa kualitas tidur berkorelasi positif dengan kecemasan, depresi dan stres pada mahasiswa kedokteran di Uttarakhand, India ${ }^{16}$.

Data penelitian ini menunjukkan sebesar 48,1\% mahasiswa mengalami kualitas tidur yang buruk. Pada analisis multivariat, ada hubungan antara kecemasan, depresi dan stres terhadap kualitas tidur mahasiswa fakultas kedokteran selama pandemik Covid-19 dengan nilai $\mathrm{p}$ dan OR masing-masing $\mathrm{p}=0,030($ OR $3,967,95 \%$ CI $[1,143-13,722]), \mathrm{p}=0,004$ (OR 11,456, 95\% CI $[2,217-59,196]), \mathrm{p}=0,043(\mathrm{OR}$ $0,314,95 \%$ CI $[0,102-0,962])$. Penelitian di India menunjukkan $34.6 \%$ dari populasi studi memiliki kualitas tidur yang buruk dengan prediktor depresi (aOR 1,337, 95\% CI [1,19-1,502]), kecemasan (aOR 1,227, 95\% CI [1.106-1.363]) dan stres (aOR 1,371, 95\% CI $[1,209-1,555])$ selama COVID-19 ${ }^{12}$. Hasil penelitian ini serupa dengan penelitian sebelumnya yang dilakukan di Itali oleh Cellini ${ }^{17}$. Penelitian di Yordania, terjadi peningkatan tingkat kecemasan dan 
depresi yang secara signifikan terkait dengan peningkatan terjadinya kualitas tidur yang buruk di antara warga Yordania selama lockdown akibat pandemi COVID-19 ${ }^{18}$. Mahasiswa kedokteran sangat rentan terhadap kualitas tidur yang buruk karena pelatihan fisik dan emosional yang menantang dan intens yang mereka lakukan ${ }^{19}$. Tidur yang buruk mempengaruhi kinerja neurokognitif dan psikomotor, kesejahteraan emosional, kapasitas kerja, kinerja akademik, kesehatan fisik dan mental serta kualitas hidup $^{20,21}$. Perubahan kualitas tidur disebabkan karena kebijakan lockdown selama pandemik dan pembatasan perjalanan yang menyebabkan siswa menghadapi penurunan fisik aktivitas, kurangnya jadwal, kondisi kehidupan yang berubah, peningkatan waktu di media sosial, dan mengubah jadwal tidur termasuk peningkatan durasi tidur siang hari ${ }^{22}$. Tidur yang buruk sudah lama dianggap sebagai gejala penting dari gangguan kesehatan mental. Gangguan tidur adalah gejala utama dari gangguan depresi ${ }^{23}$. Kecemasan dan stres berdampak negatif pada kemampuan tubuh untuk jatuh dan tetap tertidur ${ }^{24,25}$. Sebagai tambahan, peningkatan waktu yang dihabiskan di media sosial dan perangkat digital merupakan cara di mana orang dewasa muda mengatasi isolasi sosial, dan cenderung dikaitkan dengan peningkatan gangguan tidur ${ }^{26}$. Dengan demikian, temuan kami menunjukkan bahwa depresi, kecemasan, dan stres berhubungan dengan kualitas tidur pada mahasiswa fakultas kedokteran selama pandemi.

\section{SIMPULAN DAN SARAN}

Terdapat hubungan antara kecemasan, depresi dan stres dengan kualitas tidur mahasiswa FK UMS selama pandemik COVID-19. Variabel depresi merupakan variabel yang paling mempengaruhi terhadap kualitas tidur mahasiswa FK UMS selama pandemik COVID19. Namun, karena penelitian ini adalah cross sectional maka tidak dapat diketahui tentang penyebab serta mekanismenya. Dibutuhkan studi longitudinal lebih lanjut dengan jumlah sampel yang lebih besar. Mempertimbangkan temuan penelitian, dibutuhkan sesi konseling bagi mahasiswa terhadap kecemasn, depresi dan stres selama masa pandemi ini.

\section{DAFTAR PUSTAKA}

1. WHO. 2020. Archived: WHO timeline-COVID19.Available https://www.who.int/news/item/2704-2020-who-timeline---covid-19 (accessed 27 Desember 2020).

2. Kemenkes Indonesia. 2021. Archived : Situasi Terkini Perkembangan Coronavirus Disease (COVID-19) 11 Maret 2021. Available at https://covid19.kemkes.go.id/situasi-infeksiemerging/situasi-terkini-perkembangancoronavirus-disease-covid-19-11-maret-2021 (accessed 11 Maret 2021)

3. Batawi S, Tarazan N, Al-Raddadi R, Al Qasim E, Sindi A, Johni SA, Al-Hameed FM, Arabi YM, Uyeki TM, Alraddadi BM. 2019. Quality of life reported by survivors after hospitalization for 
Middle East respiratory syndrome (MERS).

Health and Quality of Life Outcomes 17(1):1-7.

4. Lotsch F, Schnyder J, Goorhuis A, Grobusch MP. 2017. Neuropsychological long-term sequelae of Ebola virus disease survivors: a systematic review. Travel Medicine and Infectious Disease 18:18-23 DOI 10.1016/j.tmaid.2017.05.001.

5. Taylor S. 2019. The psychology of pandemics: preparing for the next global outbreak of infectious disease. Cambridge: Cambridge Scholars Publishing.

6. Matthews T, Danese A, Caspi A, Fisher HL, Goldman-Mellor S, Kepa A, Moffitt TE, Odgers CL, Arseneault L. 2019. Lonely young adults in modern Britain: findings from an epidemiological cohort study. Psychological Medicine 49(2):268277 DOI 10.1017/S0033291718000788.

7. Brooks SK, Webster RK, Smith LE, Woodland L, Wessely S, Greenberg N, Rubin GJ. 2020. The psychological impact of quarantine and how to reduce it: rapid review of the evidence. Lancet 395(10227):912-920.

8. Wang C, Pan R, Wan X, Tan Y, Xu L, Ho CS, Ho R. 2020. Immediate psychological responses and associated factors during the initial stage of the 2019 coronavirus disease (COVID-19) epidemic among the general population in China.

International Journal of Environmental Research and Public Health 17(15):1729 DOI 10.3390/ijerph17051729.

9. Casagrande Maria, Francesca Favieri, Renata Tambelli, Giuseppe Forte b., 2020., The enemy who sealed the world: effects quarantine due to the COVID-19 on sleep quality, anxiety, and psychological distres in the Italian population., Sleep Medicine Volume 75, November 2020, Pages 12-20 DOI: 10.1016/j.sleep.2020.05.011
10. Bao Y, Sun Y, Meng S, Shi J, Lu LJTL. 2020. 2019-nCoV Epidemic: address mental health care to empower society. Lancet 395:e37-e38.

11. Ferrel MN, Ryan JJ. 2020. The impact of COVID19 on medical education. Cureus 12(3):e7492 DOI 10.7759/cureus.7492.

12. Saraswathi I, Saikarthik J, Senthil Kumar K, Madhan Srinivasan K, Ardhanaari M, Gunapriya R. 2020. Impact of COVID-19 outbreak on the mental health status of undergraduate medical students in a COVID-19 treating medical college: a prospective longitudinal study. PeerJ 8:e10164 DOI 10.7717/peerj.10164

13. Lee SM, Kang WS, Cho A-R, Kim T, Park JK. 2018. Psychological impact of the 2015 MERS outbreak on hospital workers and quarantined hemodialysis patients. Comprehensive Psychiatry 87:123-127 DOI

10.1016/j.comppsych.2018.10.003.

14. Ren Y, Zhou Y, Qian W, Li Z, Liu Z, Wang R, Qi L, Yang J, Song X, Zeng L, Zhang X. 2020. Letter to the editor "A longitudinal study on the mental health of general population during the COVID-19 epidemic in China". Brain, Behavior, and Immunity 87:132-133 DOI 10.1016/j.bbi.2020.05.004.

15. Al-Khani AM, Sarhandi MI, Zaghloul MS, Ewid M, Saquib NJ. 2019. A cross-sectional survey on sleep quality, mental health, and academic performance among medical students in Saudi Arabia. BMC Research Notes 12(1):665.

16. Awasthi Aanchal Anant, Neha Taneja, Sonam Maheshwari, Trisha Gupta, Bhavika. 2020. Prevalence of Internet Addiction, Poor Sleep Quality, and Depressive Symptoms Among Medical Students: A Cross-Sectional Study. Osong Public Health Res Perspect 2020;11(5):303-308. https://doi.org/10.24171/j.phrp.2020.11.5.06 
17. Cellini N, Canale N, Mioni G, Costa SJ. 2020. Changes in sleep pattern, sense of time and digital media use during COVID-19 lockdown in Italy. Journal of Sleep Research 29(4):e13074 DOI 10.1111/jsr.13074.

18. Al-Ajlouni YA, Park SH, Alawa J, et al. 2020. Anxiety and depressive symptoms are associated with poor sleep health during a period of COVID19-induced nationwide lockdown: a crosssectional analysis of adults in Jordan. BMJ Open 2020;10:e41995. doi:10.1136/ bmjopen-2020041995

19. Wong J, Patil N, Beh S, Cheung E, Wong V, Chan L, Lieh Mak F. 2005. Cultivating psychological well-being in $\mathrm{H}$ ong Kong's future doctors. Medical Teacher 27(8):715-719 DOI 10.1080/014215905002379

20. Al-Khani AM, Sarhandi MI, Zaghloul MS, Ewid M, Saquib NJ. 2019. A cross-sectional survey on sleep quality, mental health, and academic performance among medical students in Saudi Arabia. BMC Research Notes 12(1):665.

21. Giri P, Baviskar M, Phalke D. 2013. Study of sleep habits and sleep problems among medical students of Pravara Institute of Medical Sciences Loni, Western Maharashtra, India. Annals of Medical and Health Sciences Research 3(1):5154 DOI 10.4103/2141-9248.109488

22. Majumdar P, Biswas A, Sahu S. 2020. COVID-19 pandemic and lockdown: cause of sleep disruption, depression, somatic pain, and increased screen exposure of office workers and students of India. Chronobiology International 13:1-10 DOI 10.1080/07420528.2020.1786107

23. Jindal RD, Thase ME. 2004. Treatment of insomnia associated with clinical depression. Sleep Medicine Reviews 8(1):19-30 DOI 10.1016/S1087-0792(03)00025-X.
24. Coplan JD, Aaronson CJ, Panthangi V, Kim YJ. 2015. Treating comorbid anxiety and depression: psychosocial and pharmacological approaches. World Journal of Psychiatry 5(4):366 DOI 10.5498/wjp.v5.i4.366.

25. Kalmbach DA, Anderson JR, Drake CL. 2018. The impact of stres on sleep: pathogenic sleep reactivity as a vulnerability to insomnia and circadian disorders. Journal of Sleep Research 27(6):e12710 DOI 10.1111/jsr.12710.

26. Sivertsen B, Vedaa O, Harvey AG, Glozier N, Pallesen S, Aarø LE, Lønning KJ, Hysing MJ 2019. Sleep patterns and insomnia in young adults: a national survey of Norwegian university students. Journal of Sleep Research 28(2):e12790 DOI $10.1111 /$ jsr. 12790 . 